\title{
Bibliometric Studies on Emissions from Diesel Engines Running on Alcohol/Diesel Fuel Blends. A Case Study about Noise Emissions
}

\author{
María Dolores Redel-Macías ${ }^{1}$, Sara Pinzi ${ }^{2}$ (D), Meisam Babaie ${ }^{3}$, Ali Zare ${ }^{4}$, Antonio Cubero-Atienza ${ }^{1}$ (D) \\ and M. Pilar Dorado $2, *$ (D)
}

1 Departamento Ingeniería Rural, Ed Leonardo da Vinci, Campus de Rabanales, Universidad de Córdoba, Campus de Excelencia Internacional Agroalimentario, ceiA3, 14071 Córdoba, Spain; mdredel@uco.es (M.D.R.-M.); ajcubero@uco.es (A.C.-A.)

2 Dep Physical Chemistry and Applied Thermodynamics, EPS, Ed Leonardo da Vinci, Campus de Rabanales, Universidad de Córdoba, Campus de Excelencia Internacional Agroalimentario, ceiA3, 14071 Córdoba, Spain; qf1pinps@uco.es

3 School of Computing, Science and Engineering, University of Salford, Manchester M5 4NT, UK; m.babaie@salford.ac.uk

4 Flow, Aerosols \& Thermal Energy (FATE) Group, School of Engineering, Deakin University, Victoria, VIC 3216, Australia; ali.zare@deakin.edu.au

* Correspondence: pilar.dorado@uco.es; Tel.: +34-957-218-332

check for updates

Citation: Redel-Macías, M.D.; Pinzi, S.; Babaie, M.; Zare, A.; Cubero-Atienza, A.; Dorado, M.P. Bibliometric Studies on Emissions from Diesel Engines Running on Alcohol/Diesel Fuel Blends. A Case Study about Noise Emissions. Processes 2021, 9, 623. https://doi. org/10.3390/pr9040623

Academic Editor: Alfredo Iranzo

Received: 17 March 2021

Accepted: 29 March 2021

Published: 1 April 2021

Publisher's Note: MDPI stays neutral with regard to jurisdictional claims in published maps and institutional affiliations.

Copyright: (C) 2021 by the authors. Licensee MDPI, Basel, Switzerland. This article is an open access article distributed under the terms and conditions of the Creative Commons Attribution (CC BY) license (https:/ / creativecommons.org/licenses/by/ $4.0 /)$.

\begin{abstract}
The growing demand for fossil fuels, the rise in their price and many environmental concerns strengthen the incessant search for fuel alternatives. Recently, traffic noise has been described as a threat to human health and the environment, being responsible for premature deaths. In this context, the usage of alcohol/diesel fuel blends in diesel engines has gained increasing impact as a substitute fuel for use in internal combustion engines. Moreover, alcohol can be derived from environmentally friendly processes, i.e., fermentation. Furthermore, alcohols can enhance combustion characteristics due to a rise of the oxygen concentration, thus decreasing major emissions such as soot and reducing knock. The commonly used alcohols blended with diesel fuel are methanol and ethanol, recently followed by butanol. In contrast, there are very few studies about propanol blends; however, emissions reduction (including noise) could be remarkable. In the present work, an analytical literature review about noise and exhaust emissions from alcohol/diesel fuel blends was performed. The literature review analysis revealed a continuous increase in the number of publications about alcohol/diesel fuel blend exhaust emissions since 2000, confirming the growing interest in this field. However, only few publications about noise emission were found. Then, an experimental case study of noise emitted by an engine running on different alcohol (ethanol, butanol and propanol)/diesel fuel blends was presented. Experimental results showed that although diesel fuel provided the best results regarding noise emissions, butanol displayed the least deviation from that of diesel fuel among all tested alcohol blends. It may be concluded that tested alcohol/diesel fuel blends in general, and butanol blends in particular, could be a promising alternative to diesel fuel, considering noise behavior.
\end{abstract}

Keywords: blended fuels; alcohol blends; loudness; bibliometric indicator

\section{Introduction}

In the last few years, many studies have been developed to find an alternative source of energy to fossil fuel. There are several reasons for this shift, including the limitation of reserves for petroleum-based fuels, the continuous rise in price of crude oil and increasing demand for oil every year $[1,2]$. No less important are the environmental concerns; engine exhaust emissions, i.e., $\mathrm{CO}$, particulate matter (PM) or $\mathrm{NO}_{\mathrm{x}}$, have a negative influence on air quality, human wellbeing and climate [3]. Since 1992, the European Union (EU) 
has been limiting the maximum emission level from vehicles with the EURO standards. Nowadays, EURO VI is in force, which monitors more emissions and is more stringent than previous EURO standards.

Usage of alcohol/diesel fuel mixtures is very common to both reduce greenhouse gas emissions and improve some fuel properties. Due to their oxygen content, alcohols have a complete burning potential, enhancing combustion efficiency [2] and reducing soot formation, particulate matter and knock $[2,4,5]$. Low carbon-chain alcohols, i.e., methanol and ethanol, are the most often used in blend fuels. Their production could be cheaper and environmentally cleaner than that of petroleum-based fuels and biodiesel $[1,6]$. However, the use of alcohols has several disadvantages. The main drawback is the solubility with diesel fuel that may cause phase separation in some cases. This instability and potential techniques to prevent it have been thoroughly studied in the literature $[7,8]$. Solubility changes due to both composition of alcohol/diesel fuel blend and temperature. For example, ethanol (lower alcohol) blended with diesel fuel at a temperature below $10^{\circ} \mathrm{C}$ makes two immiscible phases [9]. Furthermore, both the percentage of alcohol in the blend and alcohol water content also have an influence on blending. For these reasons, some additives are used to enhance the solubility when mixed with diesel fuel. Furthermore, adding alcohol to diesel fuel improve blend properties, namely cetane number, viscosity and lubricity, as well as ignitability $[2,5,10]$. Moreover, these properties are dependent on both the chain length and the lack of complicated structures in the alcohol [2].

In spite of the problem related to their miscibility, the main advantage of alcohols is derived from the oxygen concentration, that assists in completing the combustion, reducing exhaust emissions as mentioned above. Alcohols achieve a higher latent heat of vaporization compared to diesel fuel, thus leading to a better refrigerating effect during intake and compression strokes. To reduce the dependency on fuel oil and the harmful effects on the environment, the use of alternative fuels has become mandatory in some part of the world. For this reason, the usage of alcohols, mixed with diesel fuel in certain proportions, to fuel diesel engines is suggested. Alcohol/diesel fuel blends could be an alternative to fuels derived from petroleum, as they are usually cheaper than diesel fuel and can contribute reducing exhaust emissions.

Noise constitutes another important emission, as it influences both comfort and human health. In this regard, the Directive 2002/49/EC [11] gives premises to avoid, prevent or reduce the exposure to environmental noise. In fact, traffic noise may be considered one of the main sources contributing to ambient noise. Emitted noise from a vehicle could be due to rolling, the exhaust pipe and engine. The last type may also be separated into mechanical noise and combustion noise. Moreover, combustion noise of a diesel engine may be considered the most important cause of noise in cars. Combustion noise, besides sound quality and noise emissions, are directly proportional to the in-cylinder pressure, that is induced by fuel chemical characteristics. Nowadays, automotive manufacturers make a huge effort to improve sound quality and noise emission of their engines, as they are part of the vehicle signature of the brand. For these reasons, the study of noise emission and sound quality is of great interest and plays a noticeable role from the environmental point of view and, thus, in the customer purchasing decision.

In this research, two main objectives have been proposed. Firstly, an analytical literature review about exhaust and noise emissions using alcohol/diesel fuel blends has been carried out. Although, there is a wide bibliography published related to exhaust emissions using alcohol/diesel fuel blends, to the best of our knowledge, only few references concerning noise emitted by engines running on different alcohol/diesel fuel blends were found. Therefore, and secondly, with the aim of measuring noise emissions and comparing them with those derived from the usage of diesel fuel, several alcohol/diesel fuel blends have been examined in a compression ignition engine. 


\subsection{Alcohols}

Alcohols, i.e., methanol, ethanol, propanol and butanol, are commonly used to fuel unmodified internal combustion engines. Table 1 list some physiochemical characteristics of diesel fuel and these alcohols.

Table 1. Physiochemical characteristics of diesel fuel and commonly used alcohols to fuel diesel engines [12,13].

\begin{tabular}{ccccccc}
\hline Properties & Method & Diesel Fuel & Methanol & Ethanol & Propanol & Butanol \\
\hline Chemical formulation & & $\mathrm{C}_{10} \mathrm{H}_{20}-\mathrm{C}_{15} \mathrm{H}_{28}$ & $\mathrm{CH}_{3} \mathrm{OH}$ & $\mathrm{C}_{2} \mathrm{H}_{5} \mathrm{OH}$ & $\mathrm{C}_{3} \mathrm{H}_{7} \mathrm{OH}$ & $\mathrm{C}_{4} \mathrm{H}_{9} \mathrm{OH}$ \\
\hline Density at $15^{\circ} \mathrm{C}\left(\mathrm{kg} / \mathrm{m}^{3}\right)$ & $\mathrm{EN}^{*} \mathrm{ISO}{ }^{* *} 12185$ & 835 & 791.3 & 789.4 & 803.7 & 809.7 \\
\hline Kinematic viscosity at $40{ }^{\circ} \mathrm{C}(\mathrm{cSt})$ & $\mathrm{EN} \mathrm{ISO} 3104$ & 2.72 & 0.58 & 1.13 & 1.74 & 2.22 \\
\hline Lower heating value $(\mathrm{MJ} / \mathrm{kg})$ & $\mathrm{UNE} * * 51123$ & 42.49 & 19.58 & 26.83 & 30.63 & 33.09 \\
\hline Gross heating value $(\mathrm{MJ} / \mathrm{kg})$ & $\mathrm{UNE} 51123$ & 45.54 & 22.31 & 29.67 & 33.52 & 36.02 \\
\hline Octane number & $\mathrm{EN} \mathrm{ISO} 12156$ & 52 & 5 & 8 & 12 \\
\hline Boiling point $\left({ }^{\circ} \mathrm{C}\right)$ & & $150-380$ & 64.5 & 78.4 & 97.1 & 117.7 \\
\hline Stoichiometric air/fuel ratio & & $1 / 14.67$ & $1 / 6.47$ & $1 / 9.01$ & $1 / 10.35$ & $1 / 11.19$ \\
\hline Lubricity (corrected wear scar, $\mu \mathrm{m})$ & & 315 & 1100 & 1057 & 922 & 591 \\
\hline
\end{tabular}

* Standard adopted by the European Union; ${ }^{* *}$ International Organization for Standardization; ${ }^{* *}$ Standard similar to ISO standard.

A brief bibliometric study, including previous works about alcohol/diesel fuel blend emissions, has been carried out, as shown in Figure 1. As can be seen, since 2000, a continuous increase in number of publications can be observed regarding alcohol/diesel fuel blend exhaust and noise emissions, confirming the importance and growing interest in this field. This fact draws attention to the importance of the lack of information about their behavior in terms of noise emissions.

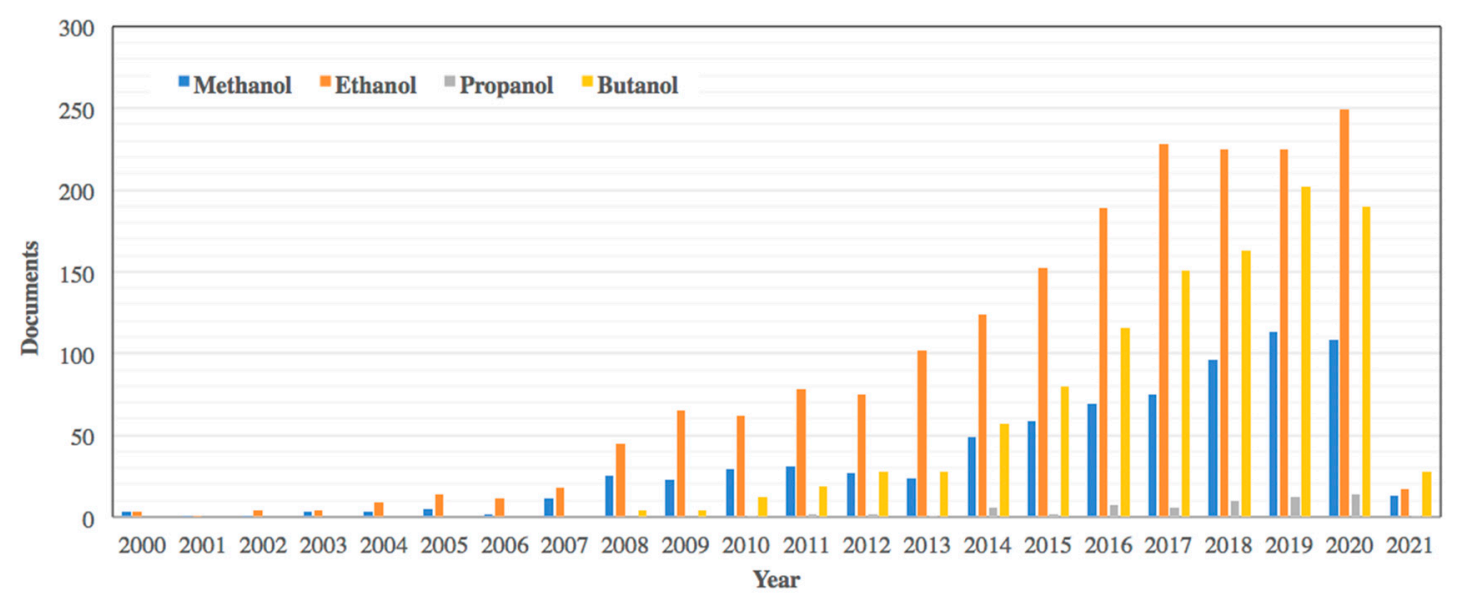

Figure 1. Number of published documents per year about alcohol/diesel fuel blends.

\subsubsection{Methanol}

Methanol is a simple compound formed by a carbon atom attached to three hydrogen atoms and a hydroxyl group $(-\mathrm{OH})$. Its chemical formula is $\mathrm{CH}_{3} \mathrm{OH}$ and is colorless, light, polar, water miscible and flammable at room temperature. Furthermore, methanol is highly toxic for humans. Methanol may be manufactured from non-fossil sources, i.e., biomass (wood, agricultural residues) and municipal wastes. However, non-renewable natural gas is the most extended raw material [14-16].

Although, at present, methanol is blended with conventional petroleum-based fuels to fuel existing engines, methanol-diesel fuel blends studies are rare compared to those 
of methanol-gasoline blends [17]. This could be due to the miscibility problem between methanol and diesel fuel. To fix this problem, the use of additives is suggested $[15,16,18]$.

Methanol's most significant parameters defining its quality as fuel are based on its high specific heat value and oxygen concentration. Methanol viscosity is below that of diesel fuel, thus injection, atomization and mixing with air is easily achieved $[16,17,19]$. However, methanol's low cetane number makes difficult autoignition, besides the elevated latent heat of vaporization and ignition temperature. Moreover it has more corrosiveness, lower density, lower energy content, poor cold-weather behavior and high aldehyde emissions than diesel fuel $[16,17,20,21]$.

Regarding the publications related to the use of methanol/diesel fuel blends, there are 781 research papers when the keywords of "methanol", "diesel fuel", "blend" and "emission" are used in Web of Science (Clarivate) search tool. These manuscripts belong to "Science Technology" (718) and "Social Sciences" (299) categories (some of them belong to both). India is leading this research, with 256 manuscripts, followed by China (161 manuscripts). Figure 2 shows the main topics found about methanol/diesel fuel blends. Thermal efficiency and biodiesel production are bolded.

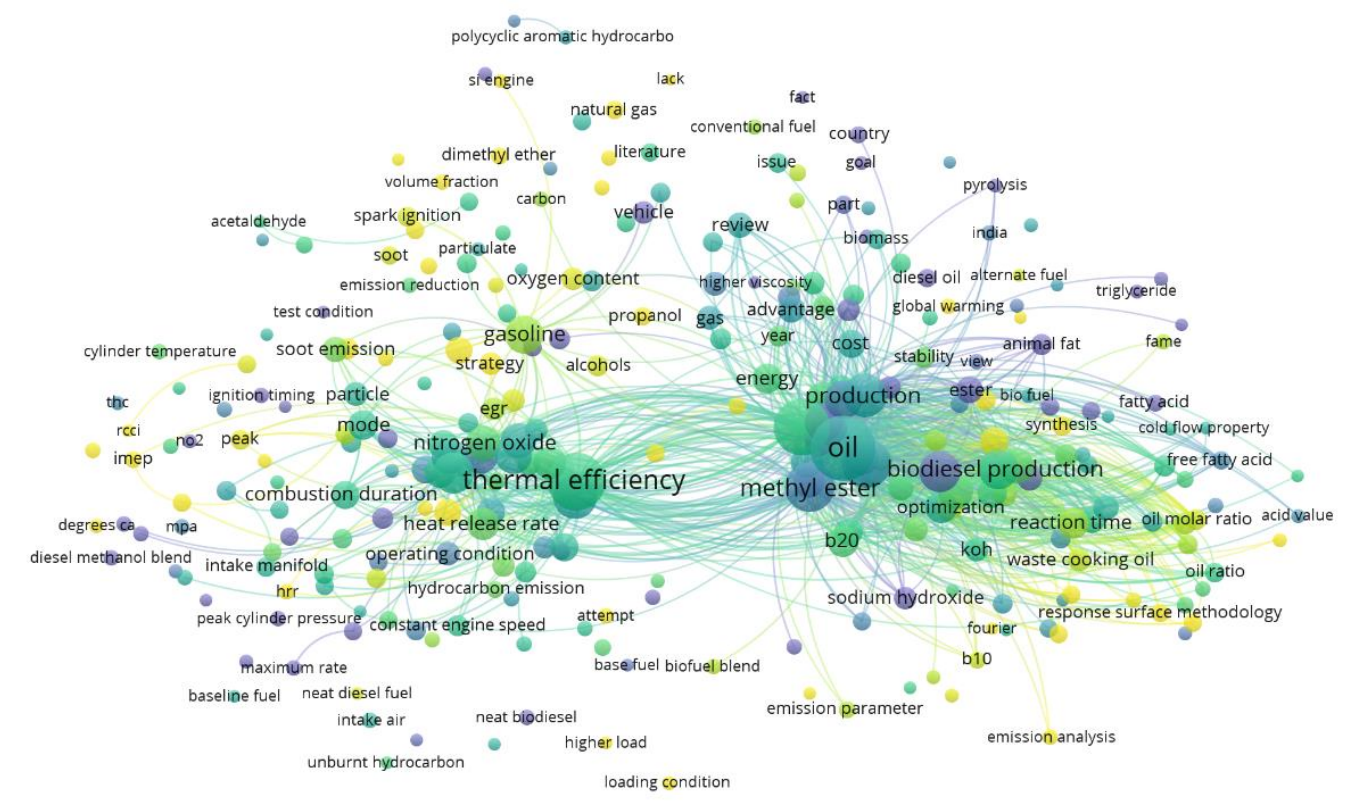

\& VOSviewer

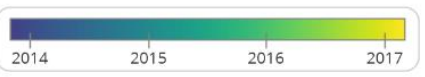

Figure 2. Research topics provided by Web of Science, Clarivate, including methanol/diesel fuel blends.

\subsubsection{Ethanol}

Ethanol, along with methanol, belongs to the lower alcohols group. It has the same chemical formula than di-methyl-ether $\left(\mathrm{C}_{2} \mathrm{H}_{6} \mathrm{O}\right)$, but with different thermodynamic behavior $[1,22,23]$. The use of ethanol in engines has been widely studied. One of the main reasons is its potential as alternative for derivate petroleum fuels. It is a renewable resource and it may be manufactured by fermentation of either sugar- or starch-rich vegetable materials, i.e., corn, barley, molasses, sugar cane, sugar beets, sorghum, etc. [24-28]. Also, other agricultural or municipal residues, i.e., straw and waste from woods, food and paper processing residues are used to produce ethanol under demonstrated processes [29-32].

Some benefits from the use of ethanol as fuel are its high oxygen concentration and low sulfur content. In spite of that, the use of straight ethanol in engines is not feasible due to technology limitations. To fix this problem, ethanol/diesel fuel blends are considered [33]. 
In this sense, several ethanol blending ratios have been studied in literature. The most important disadvantage is a consequence of its low solubility in diesel fuel, which is caused by the mixture chemical structure, temperature dependence, water content and percentage of ethanol into the blend [34]. Therefore, to solve this issue, different techniques have been applied, including mixing ethanol and diesel fuel just before injection, using an emulsifier or co-solvent, fumigating ethanol to the intake air charge or using a dual injection with a separate injection system for each fuel [7,31,35-37]. The two last options allow higher ethanol concentrations, although engine technical modifications are needed. The others allow a low percentage of ethanol, besides stabilizer additives and cetane improvers to achieve good engine performance [29,38].

Adding ethanol to diesel fuel generates physicochemical variations. The mixture viscosity and lubricity decrease, significantly affecting the lubrication of the fuel injection system [35]. The break specific fuel consumption increases as a consequence of the low heat value of ethanol, around 2/3 the value of diesel fuel [39]. Also, the lower cetane number along with its higher heat of vaporization of the blends, compared to those of straight diesel fuel, cause self-ignition resistance in diesel engines [40].

Considering exhaust emissions, ethanol has recognized advantages. Its high oxygen concentration provides a more complete combustion, thus decreasing carbon monoxide and particulate matter emissions, while increasing carbon dioxide emissions $[19,28,41]$. Also, some researchers reported an increment of carbonyl compound emissions with the use of ethanol blends [42].

The solubility of the ethanol in diesel fuel is better than that of methanol. It is caused by their difference in chemical structure and it depends on the temperature, water content and ethanol blending ratio [34]. After mixing concentrations of ethanol in diesel fuel above $12 \%$ [10], it usually forms two different phases, compromising engine functioning. To prevent it, addition of co-solvents [18] or surfactants [31,33] to the blend is recommended.

Web of Science shows 1919 research manuscripts, when keywords of "ethanol", "diesel fuel", "blend" and "emission" are used. Most of these manuscripts are classified into "Engineering" (1570), "Energy Fuels" (1479) and "Environmental Sciences Ecology" (882). Moreover, the main countries which have published in these topics were India (448), China (376) and USA (205). As may be observed from Figure 3, the main interest topics are "torque", "heat release rate", "ignition" and "delay"; noise remains unexplored with the selected research terms.

\subsubsection{Propanol}

Within higher alcohols, propanol is the one with lowest number of carbons and lower chain length. In particular, it has three carbon atoms and one hydroxyl group $(-\mathrm{OH})$. The position of this hydroxyl group defines the types of isomers and properties. It can have a renewable origin, as with other alcohols; in this case, it is called biopropanol. It is produced through a fermentation process of either sugar or starch present in biomass. The properties of propanol as fuel are similar to those of the other alcohols. Propanol viscosity, heating value and flash point are below those of diesel fuel; it provides oxygen atoms that reduce exhaust emissions [6].

The usage or addition of propanol in engines has been less reported in the literature [43]. Lapuerta et al. [2] studied some properties (including lubricity) of propanol mixed with diesel fuel. Authors found that propanol, along with butanol and pentanol, shows better solubility in diesel fuel blends than ethanol and methanol. This is due to its lower polarity. Only 60 manuscripts (out of 87 research documents) were found when "propanol", "diesel fuel", "blend" and "emission" keywords were used in the Web of Science searching tool. Moreover, 66 documents were published in "Science Technology". Figure 4 shows that the most relevant topics under study about propanol are those related to alcohol blends with "pentanol" or "butanol"; besides "emissions". 


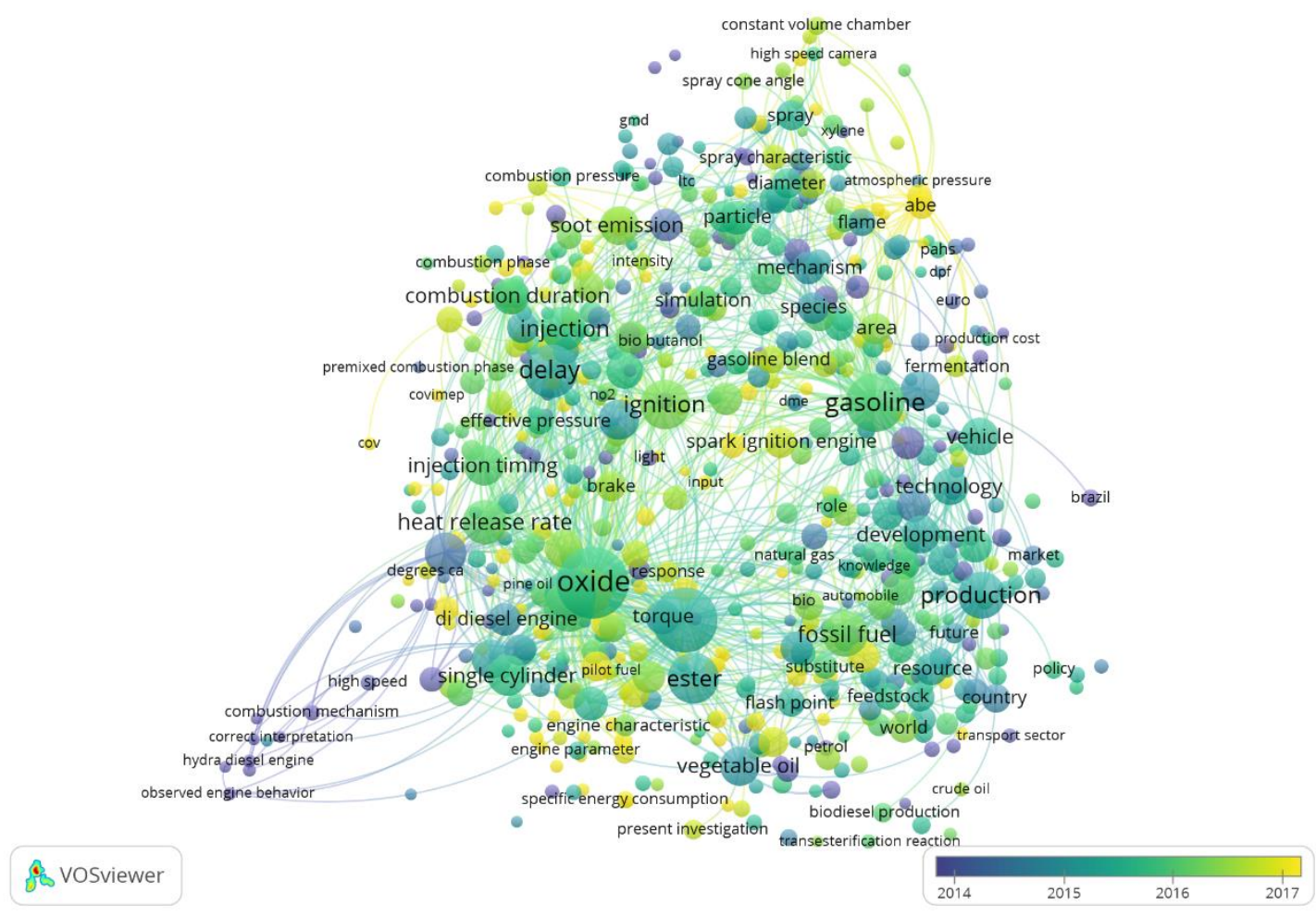

Figure 3. Research topics provided by Web of Science, Clarivate, including ethanol/diesel fuel blends.

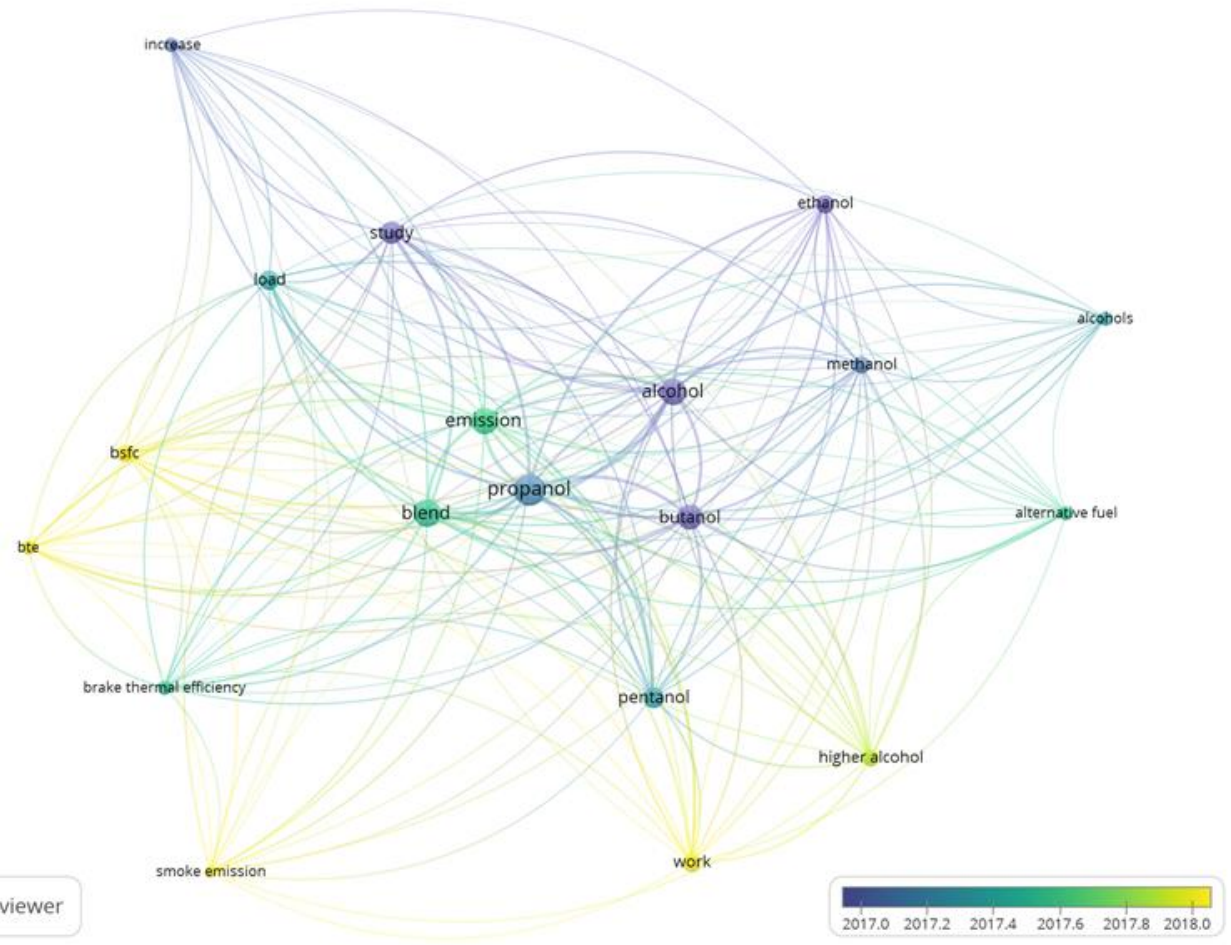

Figure 4. Research topics provided by Web of Science, Clarivate, including propanol/diesel fuel blends.

\subsubsection{Butanol}

Another alcohol that has been used as either fuel or additive is butanol. Due to its wide application as a compound in the food industry, and thus, high cost, its use as fuel is not representative. Its production from renewable raw materials is undeveloped, but 
recently it has gained interest [44]. Also, the structure of butanol is more complex than the previously discussed alcohols. It has four carbon atoms (which may form either a straight-chain or branched structure) and one hydroxyl group $(-\mathrm{OH})$ whose location defines isomers. Furthermore, each butanol isomer shows different physical properties, nonetheless their applications are very similar (solvents, industrial cleaners or gasoline additives) [45].

Interest in the addition of butanol as cosolvent, besides its use blended with diesel fuel to fuel diesel engines, is increasing yearly [27,46,47]. The properties of higher alcohols, namely butanol and pentanol, are similar to those of diesel fuel, compared to those of lower alcohols [48]. Compared to the commonly used alcohols to be mixed with diesel fuel, i.e., ethanol and methanol, butanol has higher heating value, leading to higher energy content and lower fuel consumption. It possesses higher cetane number, lower vapor pressure and lower tendency to cavitation problem. Also, its autoignition temperature is lower, which improves ignition at cold start. It is less hydrophilic, less corrosive and less likely to separate in diesel fuel blends if the fuel is contaminated with water $[22,45,48,49]$. In spite of these properties, the use of straight butanol is not compatible with some diesel engine component and its heating value is below that of conventional diesel fuel [45].

Research into butanol as an substitute fuel is increasing. Adding butanol to diesel fuel slightly raises brake specific fuel consumption and brake thermal efficiency. Exhaust gas temperature, $\mathrm{NO}_{x}, \mathrm{CO}$ emissions and smoke opacity are reduced when butanol is blended with diesel fuel, while the amount of unburned hydrocarbons may increase [48,50-53].

Regarding the publications about butanol, 1530 documents were found, 1082 in "Science Technology" and 448 in "Social Sciences"; 87 documents (60 manuscripts) were found when "propanol", "diesel fuel", "blend" and "emission" keywords were used in Web of Science search tool. Moreover, 66 documents were published in "Science Technology". Again, main countries publishing in this field are China (332 documents) and India (244 documents). For butanol, the main research is focused on "density", "injection", "gasoline" and "oxide", as shown in Figure 5.

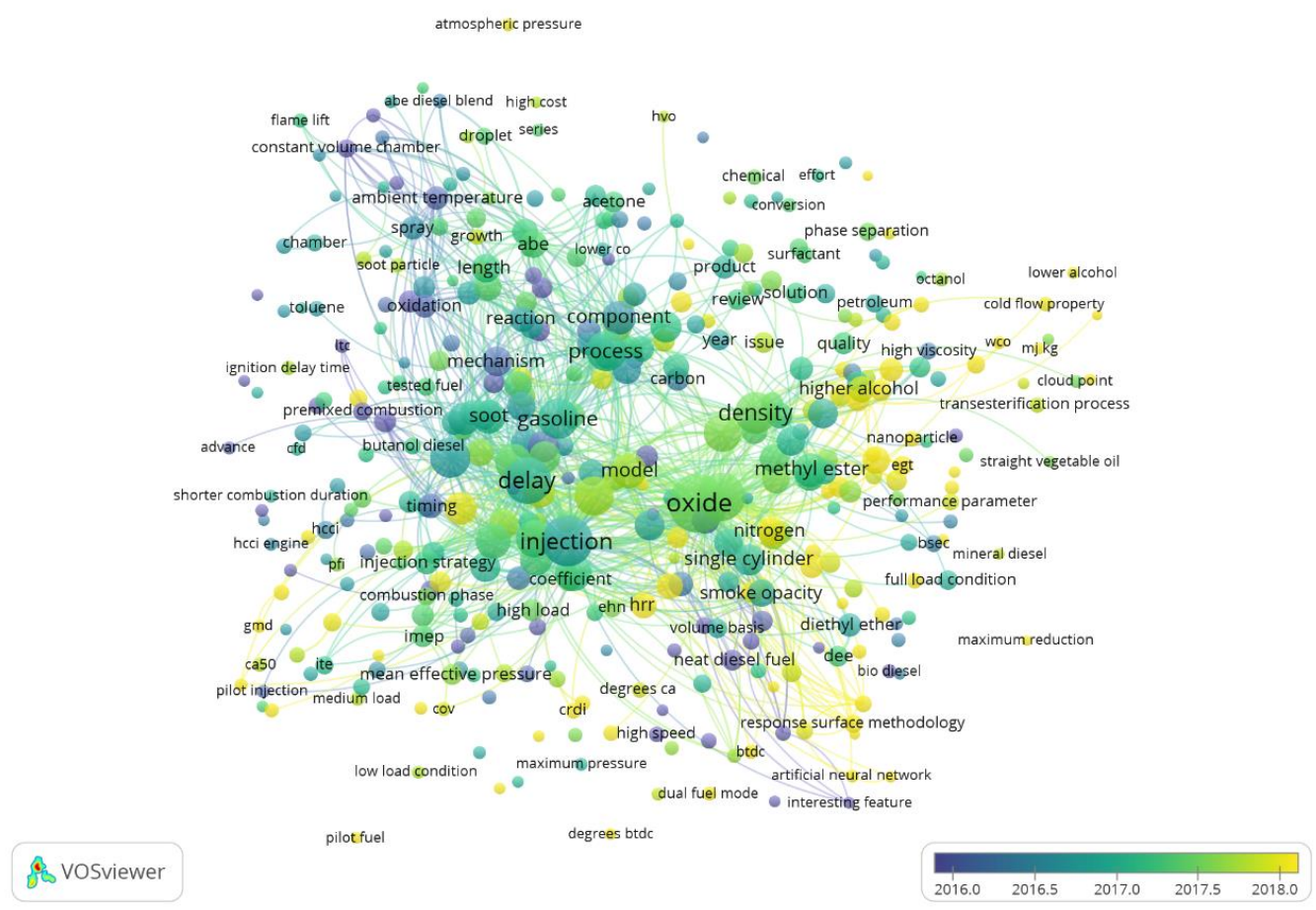

Figure 5. Research topics provided by Web of Science, Clarivate, including butanol/diesel fuel blends. 


\subsection{Noise Emissions}

The World Health Organization (WHO) warned that more than 1,000,000 European citizens are losing a healthy life due to noise every year. According to the European Environmental Agency, in the European Union (EU) almost 70 million people are exposed to more than $55 \mathrm{dBA}$ in the long-term due to traffic noise [54]. With the aim to battle the high level of exposure to noise, including traffic noise levels, a series of Directives has been established. The first one, published in 1970, was Directive 70/177/EEC; which established the limits between 82 to $91 \mathrm{dBA}$. Since then, other regulations have been published, leading to the most recent one, in 2014, Directive 540/2014/EU. In this last Directive, different modifications have been introduced, one of these related to the calculating technique and lowering the threshold noise values for each approved vehicle. Moreover, threshold noise levels are related to whole vehicle noise, instead of the engine alone or combustion noise; however, this one being one of the main sources of noise in a vehicle. In this sense, it is important to understand the noise generation mechanism in an internal combustion engine. There are three main causes of noise in a diesel engine: gas-flow, mechanical noise and combustion. The first source of noise is related to the intake and exhaust flow, due to the operation of the turbocharger unit and cooling fan. Mechanical process noise includes the contribution of gears, valve trains, as well as the piston knocking on the cylinder. Combustion noise is associated with in-cylinder pressure rise, mostly next to the ignition delay period. When the cylinder pressure rises, it provokes vibrations of the engine's block and, therefore, combustion noise radiation $[12,55]$. Therefore, both rate of fuel injected and timing have an important role in the fuel burning velocity and rate of heat release and, thus, in the combustion noise. For this reason, the physiochemical characteristics of the fuel could change previous factors, besides the injection parameters, resulting in generating more or less combustion noise.

Table 2 shows a literature revision about engine noise emissions originated from the use of ethanol, propanol, methanol, butanol blended with diesel fuel. There are limited studies in literature about noise emissions by engines fueled with different alcohol/diesel fuel blends. They were mostly condensed on engine performance and exhaust emissions. Li et al. [56] analyzed noise emissions of a diesel engine using ethanol/diesel fuel blends, and a cetane number improver. Their main conclusions were that the higher the percentage of ethanol in the blend, the higher the increase in pressure and thus, combustion noise. However, with the use of a cetane improver, a decrease in both ignition delay and cylinder peak pressure were achieved, thus reducing combustion noise. Magand et al. [57] found a drop of combustion noise with the use of ethanol/diesel fuel blends in a multi-cylinder turbocharged diesel engine, improving engine behavior. Michikawauchi et al. [58] studied exhaust and noise emissions under the New European Driving Cycle (NEDC). Results shown that at high load, combustion noise was worse when diesel fuel was used; however, low and middle loads provided lower values. Magand et al. [59] proved that combustion noise increased with the use of ethanol/diesel fuel blends, as cylinder pressure and heat release rates increased. This could be explained by the delayed combustion of the pilot injection. By contrast, other authors [60] found that the higher the presence of ethanol in the blend, the lower the combustion noise, this being due to the decrease of the cylinder pressure and heat release rates. Heuser et al. [61] demonstrated that high ethanol shares showed worse combustion noise at low load than at high load. Taghizadeh-Alisaraei and Rezaei-Asl [62] studied noise emission adding different concentrations $(2,4,6,8,10$ and $12 \%$ ) of ethanol to pure diesel fuel. Results indicated that for ethanol concentrations above $8 \%$, cylinder pressure increased, thus increasing combustion noise. Rakopoulos et al. [52] analyzed combustion noise radiation using biodiesel and n-butanol/diesel fuel blends under stationary tests. They found that due to the low cetane number of butanol, compared to that of either diesel fuel or biodiesel, minimal deviation regarding noise combustion were observed. Giakoumis et al. [63] used the same percentage of n-butanol/diesel fuel blends and diesel engine, but under transient tests. Results showed that n-butanol/diesel fuel blends exhibited higher combustion noise than straight diesel fuel, with differences 
above $4 \mathrm{~dB}(\mathrm{~A})$. Other authors [64] studied both engine vibrations and combustion noise. Their main conclusions were that butanol/diesel fuel blends showed lesser noise and vibration at low loads than diesel fuel; high loads showing the opposite trend. Morgul [65] also tested vibration and noise using butanol/diesel fuel blends. The author stated that the addition of butanol to diesel fuel increased engine vibration, while combustion noise was 2-3 dB(A) above that of straight diesel fuel. Redel-Macías et al. [13] analyzed the influence of adding propanol and ethanol to diesel fuel, in terms of noise. The authors found that the higher the percentage of alcohol in the blend, the higher the engine noise.

Table 2. Literature revision about diesel engine noise emissions resulting from the usage of alcohol/diesel fuel blends.

\begin{tabular}{|c|c|c|c|c|c|c|}
\hline Reference & Engine Type & Noise Meter & Noise Parameters & $\begin{array}{c}\text { Test } \\
\text { Conditions }\end{array}$ & $\begin{array}{c}\text { Results } \\
\text { (Compared } \\
\text { to } 100 \% \\
\text { Diesel Fuel) }\end{array}$ & $\begin{array}{l}\text { Tested } \\
\text { Blends }\end{array}$ \\
\hline [13] & $\begin{array}{c}\text { Four-cylinder } \\
\text { turbocharged } \\
\text { diesel engine } \\
(85.22 \mathrm{~kW})\end{array}$ & $\begin{array}{l}\text { GRAS prepolarized } \\
\text { free-field microphone } \\
\text { using Soundbook } \\
\text { multi-channel meter } \\
\text { with Samurai } \\
\text { v1.7 SINUS } \\
\text { MEsstechnik GmbH }\end{array}$ & $\begin{array}{l}\text { Sound pressure } \\
\text { level (dBA) }\end{array}$ & Stationary test & $\begin{array}{c}\uparrow \text { at high } \\
\text { engine load }\end{array}$ & $\begin{array}{l}\text { P30, P10, } \\
\text { P20, E10 }\end{array}$ \\
\hline [56] & $\begin{array}{l}\text { Single-cylinder } \\
\text { direct-injection } \\
\text { diesel engine } \\
(11 \mathrm{~kW})\end{array}$ & $\begin{array}{l}\text { No noise meter is } \\
\text { used. Noise is } \\
\text { estimated from } \\
\text { cylinder pressure }\end{array}$ & $\begin{array}{l}\text { Neither noise } \\
\text { parameters nor } \\
\text { noise quantification } \\
\text { are provided }\end{array}$ & & $\downarrow$ & $\begin{array}{c}\text { E0, E5, E10, } \\
\text { E25, E20 + } \\
0.2 \% \text { CN } \\
\text { improver }\end{array}$ \\
\hline [57] & $\begin{array}{l}\text { Four-cylinder } \\
\text { turbocharged } \\
\text { common rail } \\
\text { injection diesel } \\
\text { engine }(66 \mathrm{~kW})\end{array}$ & Noise is simulated & $\mathrm{dB}$ & $\begin{array}{l}\text { New European } \\
\text { Driving Cycle } \\
\text { (NEDC) }\end{array}$ & $\downarrow$ & $\begin{array}{l}\text { E0, E5, E10, } \\
\text { E25, E20 }\end{array}$ \\
\hline$[58]$ & $\begin{array}{l}\text { Four-cylinder } \\
\text { common rail } \\
\text { injection } \\
\text { diesel engine }\end{array}$ & $\begin{array}{l}\text { AVL combustion } \\
\text { noise meter } 450 \\
\text { based on } \\
\text { cylinder pressure }\end{array}$ & $\begin{array}{l}\text { Neither noise } \\
\text { parameters nor } \\
\text { noise quantification } \\
\text { are provided }\end{array}$ & NEDC & $\downarrow$ & B10-B30 \\
\hline [59] & $\begin{array}{l}\text { Four-cylinder } \\
\text { diesel engine } \\
(66 \mathrm{~kW})\end{array}$ & $\begin{array}{l}\text { No noise meter is } \\
\text { used. Noise is } \\
\text { estimated from } \\
\text { cylinder pressure }\end{array}$ & $\mathrm{dB}$ & NEDC & $\uparrow$ & E0, E20 \\
\hline$[60]$ & $\begin{array}{l}\text { Four-cylinder } \\
\text { diesel engine } \\
(100 \mathrm{~kW})\end{array}$ & $\begin{array}{l}\text { No noise meter is } \\
\text { used. Noise is } \\
\text { estimated from } \\
\text { ringing intensity }\end{array}$ & $\begin{array}{l}\text { Neither noise } \\
\text { parameters nor } \\
\text { noise quantification } \\
\text { are provided }\end{array}$ & & $\downarrow$ & $\begin{array}{l}\text { E0, E10, } \\
\text { E20, E30 }\end{array}$ \\
\hline [61] & $\begin{array}{l}\text { Single-cylinder } \\
\text { diesel engine } \\
(80 \mathrm{~kW})\end{array}$ & $\begin{array}{l}\text { No noise meter is } \\
\text { used. Noise is } \\
\text { estimated from } \\
\text { cylinder pressure }\end{array}$ & $\begin{array}{l}\text { Neither noise } \\
\text { parameters nor } \\
\text { noise quantification } \\
\text { are provided }\end{array}$ & Stationary test & $\downarrow$ & $\begin{array}{l}\text { Ethanol/diesel } \\
\text { fuel blends }\end{array}$ \\
\hline [62] & $\begin{array}{l}\text { Six-cylinder } \\
\text { diesel engine } \\
\quad(92 \mathrm{~kW})\end{array}$ & $\begin{array}{l}\text { Three accelerometers } \\
\text { are used }\end{array}$ & $\begin{array}{l}\text { Neither noise } \\
\text { parameters nor } \\
\text { noise quantification } \\
\text { are provided }\end{array}$ & Stationary test & $\uparrow($ for E8) & $\begin{array}{c}\text { D100, D98E2, } \\
\text { D96E4, } \\
\text { D94E6, } \\
\text { D92E8, } \\
\text { D90E10, } \\
\text { D88E12 }\end{array}$ \\
\hline
\end{tabular}


Table 2. Cont.

\begin{tabular}{|c|c|c|c|c|c|c|}
\hline Reference & Engine Type & Noise Meter & Noise Parameters & $\begin{array}{c}\text { Test } \\
\text { Conditions }\end{array}$ & $\begin{array}{c}\text { Results } \\
\text { (Compared } \\
\text { to } 100 \% \\
\text { Diesel Fuel) }\end{array}$ & $\begin{array}{l}\text { Tested } \\
\text { Blends }\end{array}$ \\
\hline [52] & $\begin{array}{l}\text { Six-cylinder } \\
\text { direct injection } \\
\text { turbocharged } \\
\text { diesel engine } \\
\text { (power } 177 \mathrm{~kW} \text { ) }\end{array}$ & $\begin{array}{l}\text { AVL combustion } \\
\text { noise meter } 450 \\
\text { based on } \\
\text { cylinder pressure }\end{array}$ & $\mathrm{dB}$ & Stationary test & $\begin{array}{l}\text { Minimal } \\
\text { noise } \\
\text { deviation }\end{array}$ & $\begin{array}{l}\text { D100, } \\
\text { D7030BD, } \\
\text { D75B25 }\end{array}$ \\
\hline [63] & $\begin{array}{l}\text { Six-cylinder } \\
\text { direct injection } \\
\text { turbocharged } \\
\text { diesel engine } \\
(177 \mathrm{~kW})\end{array}$ & $\begin{array}{l}\text { AVL combustion } \\
\text { noise meter } 450 \\
\text { based on } \\
\text { cylinder pressure }\end{array}$ & dBA & Transient test & $\uparrow$ & $\begin{array}{l}\text { D100, } \\
\text { D70BD30, } \\
\text { D75B25 }\end{array}$ \\
\hline [64] & $\begin{array}{l}\text { Single-cylinder } \\
\text { direct injection } \\
\text { diesel engine } \\
(7.4 \mathrm{~kW})\end{array}$ & $\begin{array}{c}\text { LabVIEW software at } \\
\text { a sampling frequency } \\
\text { of } 25.6 \mathrm{kHz} . \mathrm{B} \& \mathrm{~K} \\
\text { noise acquisition } \\
\text { system } \\
\text { (microphones) }\end{array}$ & $\mathrm{dBA}$ & Stationary test & $\begin{array}{c}\uparrow \text { at high } \\
\text { engine load }\end{array}$ & $\begin{array}{c}\mathrm{D} 100, \mathrm{~B} 1, \mathrm{~B} 2, \\
\mathrm{~B} 3, \mathrm{~B} 4\end{array}$ \\
\hline [65] & $\begin{array}{l}\text { Single-cylinder } \\
\text { direct injection } \\
\text { diesel engine } \\
(5.5 \mathrm{~kW})\end{array}$ & $\begin{array}{c}\text { Triaxial } \\
\text { accelerometer B\&K } \\
\text { 4535-B, RT Photon } \\
\text { and software }\end{array}$ & LAeq (dBA) & Stationary test & $\uparrow 1-2 \mathrm{dBA}$ & $\begin{array}{l}\text { D100, B10, } \\
\text { D90 }\end{array}$ \\
\hline
\end{tabular}

B: Butanol; BD: Biodiesel; E: Ethanol (Ex, Bx, Px: percentage of ethanol, butanol or pentanol, respectively, blended with diesel fuel); D: Diesel fuel; P: Propanol. GRAS is a make of an instrument, AVL is a make of an instrument.

Figure 6 depicts the results provided by Web of Science after using the keywords "noise", "alcohol blends", "methanol", "ethanol", "propanol" and "pentanol" in the searching tool. Moreover, this search was refined for "Energy Fuels" category. A total of 65 documents were found; the USA, India and Turkey are leading research concerning noise from diesel engines running on alcohol blends, with 17, 10 and 9 scientific documents, respectively.

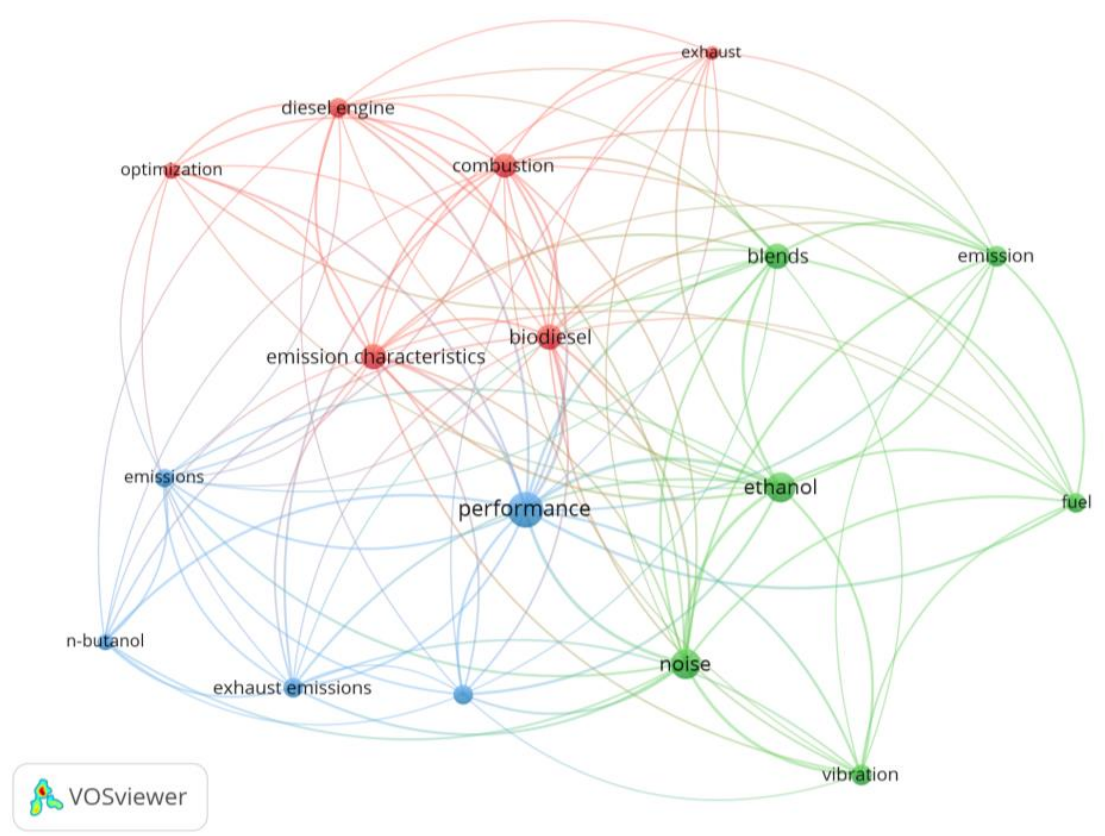

Figure 6. Research topics provided by Web of Science, Clarivate, including noise and alcohol/diesel fuel blends. 


\section{Materials and Methods}

A 4-cylinder turbocharged, intercooled common rail injection 2.31 Euro 3 diesel engine Nissan M9T (140 kW at $3750 \mathrm{~min}^{-1}$ and $450 \mathrm{Nm}$ at 1500-2500 $\mathrm{min}^{-1}$ ) was used. The engine test bench was furnished with a Horiba DYNAS3 LI dynamometer (Kyoto, Japan), monitored with a STARS system (This is a make of the control system).

Piezoelectric Kistler sensors (Winterthur Wülflingen, Switzerland) were used to analyze combustion chamber pressure. They were placed inside the adapter of the cylinder, matching dimensions of the glow plug. Information from pressure and crank angle degree were acquired with a Kibox, Kistler (Winterthur Wülflingen, Switzerland).

Ultra-low-sulfur diesel fuel (ULSD) was used as reference fuel for initial test, followed by $10 \%(v / v)(\mathrm{B} 10)$ and 20\% $(v / v)(\mathrm{B} 20)$ n-butanol/diesel fuel blends, $10 \%(v / v)(\mathrm{P} 10)$ and $20 \%(v / v)(\mathrm{P} 20)$ propanol/diesel fuel blends and 10\% (v/v) (E10) ethanol/diesel fuel blend. Blends were prepared at different proportions, taking into consideration fuel properties, i.e., density, cetane number and oxygen content. Steady-state points used in this work are depicted in Table 3.

Table 3. Design of experiments comprising selected five steady-state operating modes.

\begin{tabular}{ccc}
\hline MODE NO. & ENGINE SPEED $\left(\mathbf{m i n}^{-\mathbf{1}}\right)$ & TORQUE $\mathbf{~ N m})$ \\
\hline $\mathbf{1}$ & 1500 & 25 \\
$\mathbf{2}$ & 1700 & 50 \\
$\mathbf{3}$ & 1900 & 100 \\
$\mathbf{4}$ & 2100 & 250 \\
$\mathbf{5}$ & 2500 & 30 \\
\hline
\end{tabular}

Noise emissions were measured using a supervisory control and data acquisition (SCADA) multichannel equipment LMS mobile (This is a make of an instrument.), a 36microphone array model TL-AHW 16.1 and Siemens LMS TestLab software. Besides sound pressure level (SPL), loudness was calculated. This parameter is important to provide the correct human hearing equivalent sound perception. Taking into consideration accessible methodologies, only that provided by Zwicker and Fastl [66] is effective to broadband excitation. Subsequently, this technique was selected, as it fulfils ISO 532B, DIN 45,631 and $\mathrm{ISO} / \mathrm{R} 131$ requirements.

\section{Results}

Figure 7 shows the SPL spectrograph for alcohol/diesel fuel blends. It may be seen that highest noise level is found at high engine speed, mainly for propanol/diesel fuel blends. Better results compared to those of diesel fuel are achieved for butanol/diesel fuel blends, regardless engine speed or torque. As an example, there is a significant decrease in noise level, almost $8 \mathrm{~dB}(\mathrm{~A})$, when engine speed changes from $2408 \mathrm{rpm}$ to $1431 \mathrm{rpm}$. This could be due to the engine injection strategy (load shifts injection timing, ignition delay and therefore, decreases in-cylinder pressure). Although, the best results regarding noise emissions are achieved by diesel fuel, when alcohol/diesel fuel blends are used, butanol provides minimal deviation in comparison to those of diesel fuel. This may be explained by the similarity between fuel properties of both petroleum-based fuel and high carbon-chain alcohols. Its high cetane number is producing a reduction of the ignition delay period, which decreases the cylinder pressure rise rate (Figure 7) and thus, combustion noise emission $[56,67,68]$. The shorter the alcohol carbon-chain, the higher the oxygen concentration and the lower the cetane number. The lower the cetane number, the higher the ignition timing, ignition delay, in-cylinder pressure and therefore, combustion noise [22]. 


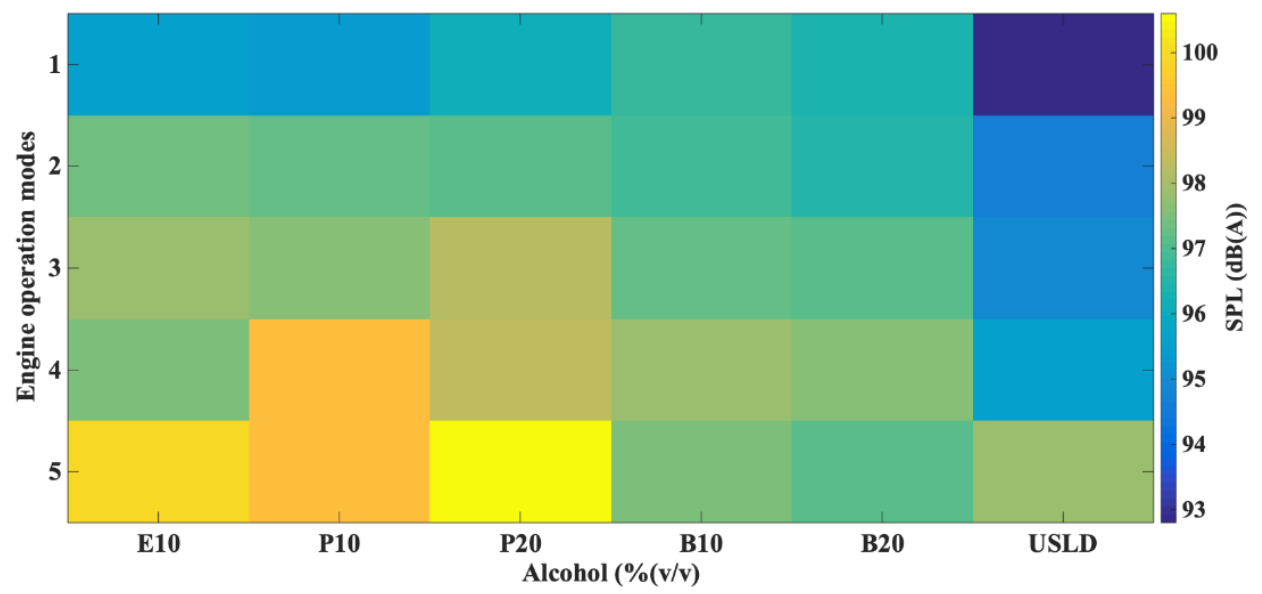

Figure 7. Sound pressure level (SPL) for alcohol/diesel fuel blends; $10 \%(v / v)$ ethanol/diesel fuel (E10), 10\% (v/v) propanol/diesel fuel (P10), 20\% (v/v) propanol/diesel fuel (P20), 10\% $(v / v)$ butanol/diesel fuel (B10), 20\% (v/v) butanol/diesel fuel (B20) and 100\% ultra-low -sulfur diesel fuel (USLD).

The engine selected for this research was an old monopoint injection Euro 3 diesel engine, with higher burnt fuel, compared to new engines. Thus, this led to higher heat release at the first phase of the combustion, when short carbon-chain alcohol/diesel fuel blends were used (Figure 8). This effect could be eliminated in different ways, i.e., changing the injection angle, using additives (as cetane improver to increase cetane number), decreasing the ignition timing and using a modern engine with common rail or multipoint injection systems.

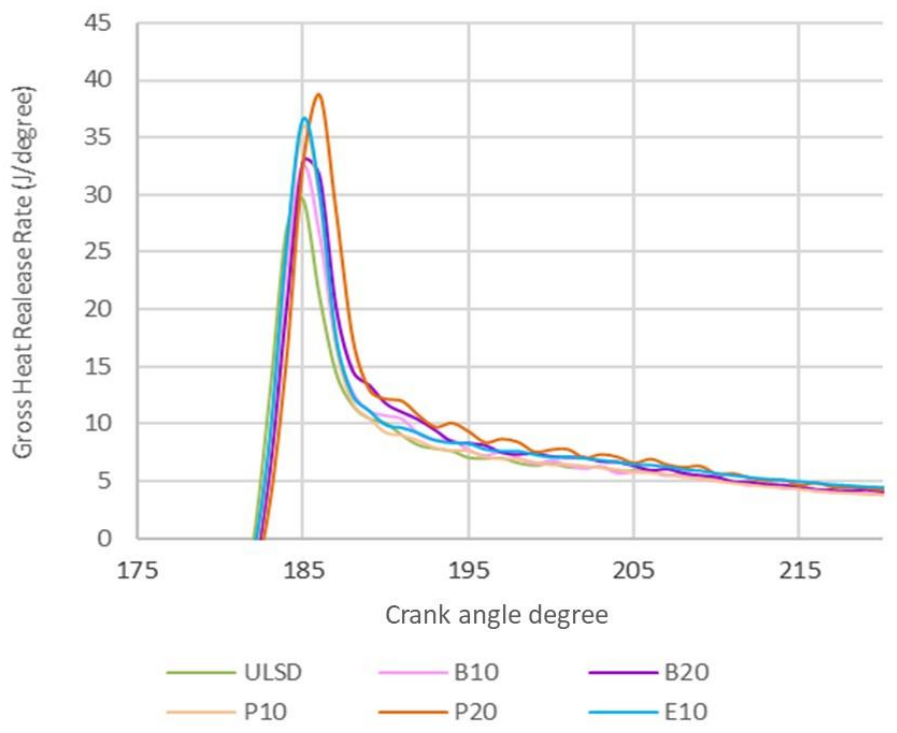

Figure 8. Heat release rate of point 1 of different alcohol/diesel fuel blends; $10 \%(v / v)$ ethanol/diesel fuel (E10), 10\% $(v / v)$ propanol/diesel fuel (P10), 20\% $(v / v)$ propanol/diesel fuel (P20), 10\% $(v / v)$ butanol/diesel fuel (B10), 20\% (v/v) butanol/diesel fuel (B20) and 100\% ultra-low -sulfur diesel fuel (USLD).

Figure 9 shows noise perception by means of loudness parameters. As can be seen, overall, the higher the loudness, the higher the annoyance of the noise. In this case, low percentages of propanol in the blend reduce the loudness and thus, the annoyance compared to results derived from the use of higher concentrations of propanol in mixtures. The best results in term of loudness are achieved by butanol blends. This may suggest 
that propanol/diesel fuel blends are responsible of a light rise of the ignition delay period, compared to other alcohol/diesel fuel blends, which ends up in a superior cylinder pressure increase rate and, subsequently, higher noise emission, mainly due to the high engine speed. As can be seen from our results, loudness rises with the content of lower alcohol in the mixture, especially at high load, achieving values up to 110 sones.

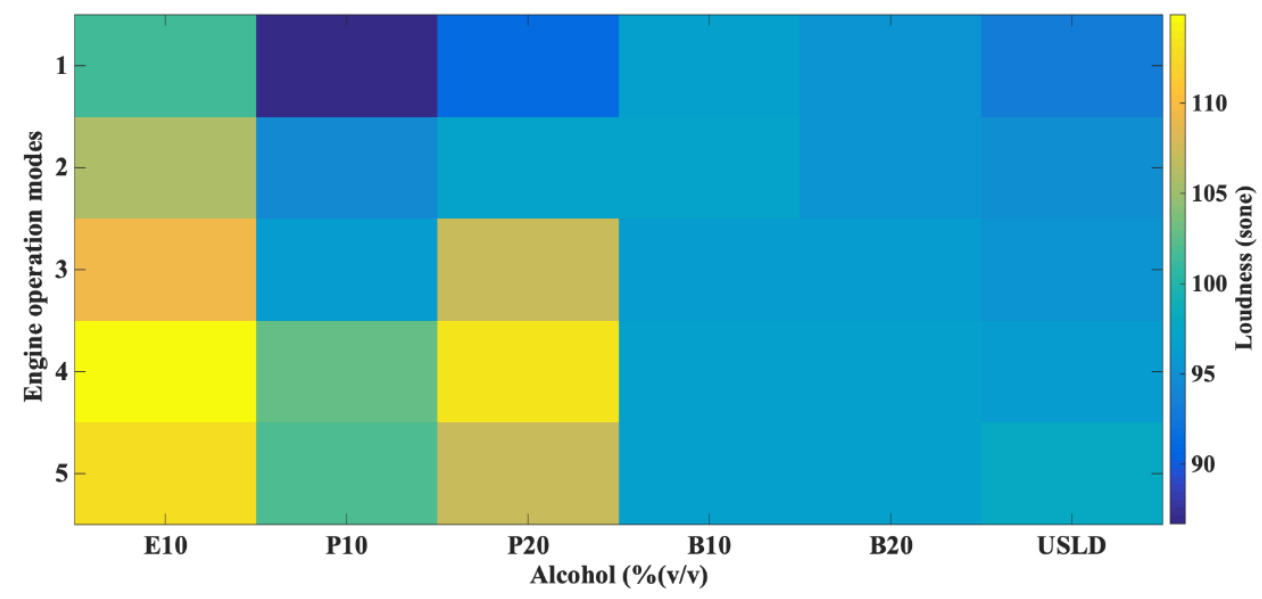

Figure 9. Loudness for alcohol diesel fuel blends; $10 \%(v / v)$ ethanol/diesel fuel (E10), 10\% $(v / v)$ propanol/diesel fuel (P10), 20\% (v/v) propanol/diesel fuel (P20), 10\% (v/v) butanol/diesel fuel (B10), $20 \%(v / v)$ butanol/diesel fuel (B20) and 100\% ultra-low -sulfur diesel fuel (USLD).

\section{Conclusions}

An analytical review into the use of alcohol/diesel fuel blends as potential substitutes for derived petroleum-based fuel has been conducted. A bibliometric analysis of the published manuscripts using alcohol/diesel fuel blends has been included. In this regard, only a few works about noise emissions using alcohol/diesel fuel blends have been found in the literature. Moreover, noise emission is mostly estimated, instead of measured. Therefore, noise emissions and loudness (sound quality parameter) of a diesel engine fueled with alcohol/diesel fuel blends have been studied. Oxygen concentration of the studied alcohol fuel components, as well as cetane number, were identified as the dominant fuel properties that led to reductions of noise and loudness. In fact, similarities between fuel properties (oxygen content and cetane number) of both petroleum-based fuel and high carbon-chain alcohols led to similar noise results. The shorter the alcohol carbon-chain, the higher the oxygen concentration and the lower the cetane number. The lower the cetane number, the higher the ignition timing, ignition delay, in-cylinder pressure and, therefore, combustion noise. As a general trend, it may be stated that butanol/diesel fuel blends exhibit lower noise emissions compared to other alcohol/diesel fuel blends.

Author Contributions: Conceptualization: M.D.R.-M., S.P., M.P.D.; Methodology, M.D.R.-M., M.B. and A.Z.; Formal Analysis, all authors; Writing-Original Draft Preparation, M.D.R.-M. and S.P.; Writing-Review and Editing, A.C.-A. and M.P.D.; Supervision, A.C.-A. and M.P.D.; Funding Acquisition, M.P.D. All authors have read and agreed to the published version of the manuscript.

Funding: The authors appreciate the economic funding offered by the Spanish Ministry of Science and Research, through grant no. PID2019-105936RB-C21 and the European Regional Development Fund (ERDF), Andalusian Counselling of Economy, Knowledge and Enterprise, and University of Cordoba, Spain (INMUNOWASTE 1260770).

Conflicts of Interest: The authors declare no conflict of interest. 


\section{References}

1. Agarwal, A.K. Biofuels (alcohols and biodiesel) applications as fuels for internal combustion engines. Prog. Energy Combust. Sci. 2007, 33, 233-271. [CrossRef]

2. Armas, O.; Cárdenas, D.; García-Contreras, R.; Mata, C. Bioethanol-Diesel Blends Used in Diesel Engines and Vehicles under Transient Operation. 2020. Available online: https:/ / www.intechopen.com/online-first/bioethanol-diesel-blends-used-in-dieselengines-and-vehicles-under-transient-operation (accessed on 26 March 2021).

3. Gaffney, J.S.; Marley, N.A. The impacts of combustion emissions on air quality and climate-From coal to biofuels and beyond. Atmos. Environ. 2009, 43, 23-36. [CrossRef]

4. Lapuerta, M.; Armas, O.; Garcia-Contreras, R. Stability of diesel-bioethanol blends for use in diesel engines. Fuel 2007, 86, 1351-1357. [CrossRef]

5. Ribeiro, N.M.; Pinto, A.C.; Quintella, C.M.; da Rocha, G.O.; Teixeira, L.S.G.; Guarieiro, L.L.N.; Rangel, M.D.; Veloso, M.C.C.; Rezende, M.J.C.; da Cruz, R.S.; et al. The role of additives for diesel and diesel blended (ethanol or biodiesel) fuels: A review. Energy Fuels 2007, 21, 2433-2445. [CrossRef]

6. Laza, T.; Bereczky, A. Basic fuel properties of rapeseed oil-higher alcohols blends. Fuel 2011, 90, 803-810. [CrossRef]

7. Abu-Qudais, M.; Haddad, O.; Qudaisat, M. The effect of alcohol fumigation on diesel engine performance and emissions. Energy Convers. Manag. 2000, 41, 389-399. [CrossRef]

8. Lapuerta, M.; Garcia-Contreras, R.; Campos-Fernandez, J.; Dorado, M.P. Stability, lubricity, viscosity, and cold-flow properties of alcohol-diesel blends. Energy Fuels 2010, 24, 4497-4502. [CrossRef]

9. Hansen, A.C.; Zhang, Q.; Lyne, P.W.L. Ethanol-diesel fuel blends-A review. Bioresour. Technol. 2005, 96, 277-285. [CrossRef]

10. Campos-Fernandez, J.; Arnal, J.M.; Gomez, J.; Dorado, M.P. A comparison of performance of higher alcohols/diesel fuel blends in a diesel engine. Appl. Energy 2012, 95, 267-275. [CrossRef]

11. Directive 2002/49/EC of the European Parliament and of the Council of 25 June 2002 Relating to the Assessment and Management of Environmental Noise-Declaration by the Commission in the Conciliation Ommittee on the Directive Relating to the Assessment and Managament of Enviromental Noise. 2002. Available online: https://eur-lex.europa.eu/legal-content/EN/ TXT / ?uri=celex\%3A32002L0049 (accessed on 26 March 2021).

12. Giakoumis, E.G.; Rakopoulos, D.C.; Rakopoulos, C.D. Combustion noise radiation during dynamic diesel engine operation including effects of various biofuel blends: A review. Renew. Sustain. Energy Rev. 2016, 54, 1099-1113. [CrossRef]

13. Redel-Macías, M.D.; Leiva-Candia, D.E.; Soriano, J.A.; Herreros, J.M.; Cubero-Atienza, A.J.; Pinzi, S. Influence of short carbonchain alcohol (ethanol and 1-propanol)/diesel fuel blends over diesel engine emissions. Energies 2021, 14, 1309. [CrossRef]

14. Liu, Y.Z.; Jiao, W.Z.; Qi, G.S. Preparation and properties of methanol-diesel oil emulsified fuel under high-gravity environment. Renew. Energy 2011, 36, 1463-1468. [CrossRef]

15. Chao, M.R.; Lin, T.C.; Chao, H.R.; Chang, F.H.; Chen, C.B. Effects of methanol-containing additive on emission characteristics from a heavy-duty diesel engine. Sci. Total Environ. 2001, 279, 167-179. [CrossRef]

16. Sayin, C.; Ilhan, M.; Canakci, M.; Gumus, M. Effect of injection timing on the exhaust emissions of a diesel engine using diesel-methanol blends. Renew. Energy 2009, 34, 1261-1269. [CrossRef]

17. Anand, K.; Sharma, R.P.; Mehta, P.S. Experimental investigations on combustion, performance and emissions characteristics of neat karanji biodiesel and its methanol blend in a diesel engine. Biomass Bioenergy 2011, 35, 533-541. [CrossRef]

18. Bayraktar, H. An experimental study on the performance parameters of an experimental CI engine fueled with diesel-methanoldodecanol blends. Fuel 2008, 87, 158-164. [CrossRef]

19. Sayin, C. Engine performance and exhaust gas emissions of methanol and ethanol-diesel blends. Fuel 2010, 89, 3410-3415. [CrossRef]

20. Sayin, C.; Ozsezen, A.N.; Canakci, M. The influence of operating parameters on the performance and emissions of a DI diesel engine using methanol-blended-diesel fuel. Fuel 2010, 89, 1407-1414. [CrossRef]

21. Yao, C.D.; Cheung, C.S.; Cheng, C.H.; Wang, Y.S.; Chan, T.L.; Lee, S.C. Effect of diesel/methanol compound combustion on diesel engine combustion and emissions. Energy Convers. Manag. 2008, 49, 1696-1704. [CrossRef]

22. Giakoumis, E.G.; Rakopoulos, C.D.; Dimaratos, A.M.; Rakopoulos, D.C. Exhaust emissions with ethanol or n-butanol diesel fuel blends during transient operation: A review. Renew. Sustain. Energy Rev. 2013, 17, 170-190. [CrossRef]

23. Armas, O.; Lapuerta, M.; Mata, C.; Pérez, D. Online emissions from a vibrating roller using an ethanol- diesel blend during a railway construction. Energy Fuels 2009, 23, 2989-2996. [CrossRef]

24. Misra, R.D.; Murthy, M.S. Blending of additives with biodiesels to improve the cold flow properties, combustion and emission performance in a compression ignition engine-A review. Renew. Sustain. Energy Rev. 2011, 15, 2413-2422. [CrossRef]

25. Lu, X.C.; Yang, J.G.; Zhang, W.G.; Huang, Z. Effect of cetane number improver on heat release rate and emissions of high speed diesel engine fueled with ethanol-diesel blend fuel. Fuel 2004, 83, 2013-2020.

26. Can, O.; Celikten, I.; Usta, N. Effects of ethanol addition on performance and emissions of a turbocharged indirect injection Diesel engine running at different injection pressures. Energy Convers. Manag. 2004, 45, 2429-2440. [CrossRef]

27. Huang, J.C.; Wang, Y.D.; Li, S.D.; Roskilly, A.P.; Yu, H.D.; Li, H.F. Experimental investigation on the performance and emissions of a diesel engine fuelled with ethanol-diesel blends. Appl. Therm. Eng. 2009, 29, 2484-2490. [CrossRef]

28. Ajav, E.A.; Singh, B.; Bhattacharya, T.K. Experimental study of some performance parameters of a constant speed stationary diesel engine using ethanol-diesel blends as fuel. Biomass Bioenergy 1999, 17, 357-365. [CrossRef] 
29. Chen, H.; Wang, J.X.; Shuai, S.J.; Chen, W.M. Study of oxygenated biomass fuel blends on a diesel engine. Fuel 2008, 87, 3462-3468. [CrossRef]

30. Chen, H.; Shual, S.J.; Wang, J.X. Study on combustion characteristics and PM emission of diesel engines using ester-ethanol-diesel blended fuels. Proc. Combust. Inst. 2007, 31, 2981-2989. [CrossRef]

31. Rakopoulos, D.C.; Rakopoulos, C.D.; Papagiannakis, R.G.; Kyritsis, D.C. Combustion heat release analysis of ethanol or n-butanol diesel fuel blends in heavy-duty DI diesel engine. Fuel 2011, 90, 1855-1867. [CrossRef]

32. Rakopoulos, D.C.; Rakopoulos, C.D.; Kakaras, E.C.; Giakoumis, E.G. Effects of ethanol-diesel fuel blends on the performance and exhaust emissions of heavy duty DI diesel engine. Energy Convers. Manag. 2008, 49, 3155-3162. [CrossRef]

33. Park, S.H.; Youn, I.M.; Lee, C.S. Influence of ethanol blends on the combustion performance and exhaust emission characteristics of a four-cylinder diesel engine at various engine loads and injection timings. Fuel 2011, 90, 748-755. [CrossRef]

34. Kwanchareon, P.; Luengnaruemitchai, A.; Jai-In, S. Solubility of a diesel-biodiesel-ethanol blend, its fuel properties, and its emission characteristics from diesel engine. Fuel 2007, 86, 1053-1061. [CrossRef]

35. Pidol, L.; Lecointe, B.; Starck, L.; Jeuland, N. Ethanol-biodiesel-diesel fuel blends: Performances and emissions in conventional diesel and advanced low temperature combustions. Fuel 2012, 93, 329-338. [CrossRef]

36. Lei, J.L.; Bi, Y.H.; Shen, L.Z. Performance and emission characteristics of diesel engine fueled with ethanol-diesel blends in different altitude regions. J. Biomed. Biotechnol. 2011, 2011, 417421. [CrossRef]

37. Sahin, Z.; Durgun, O. Theoretical investigation of effects of light fuel fumigation on diesel engine performance and emissions. Energy Convers. Manag. 2007, 48, 1952-1964. [CrossRef]

38. de Caro, P.S.; Mouloungui, Z.; Vaitilingom, G.; Berge, J.C. Interest of combining an additive with diesel-ethanol blends for use in diesel engines. Fuel 2001, 80, 565-574. [CrossRef]

39. Li, D.; Huang, Z.; Lu, X.C.; Zhang, W.; Yang, J. Physico-chemical properties of ethanol-diesel blend fuel and its effect on performance and emissions of diesel engines. Renew. Energy 2005, 30, 967-976. [CrossRef]

40. Kim, H.; Choi, B. Effect of ethanol-diesel blend fuels on emission and particle size distribution in a common-rail direct injection diesel engine with warm-up catalytic converter. Renew. Energy 2008, 33, 2222-2228. [CrossRef]

41. Armas, O.; García-Contreras, R.; Ramos, Á. Pollutant emissions from New European Driving Cycle with ethanol and butanol diesel blends. Fuel Process. Technol. 2014, 122, 64-71. [CrossRef]

42. Song, C.L.; Zhao, Z.A.; Lv, G.; Song, J.N.; Liu, L.D.; Zhao, R.F. Carbonyl compound emissions from a heavy-duty diesel engine fueled with diesel fuel and ethanol-diesel blend. Chemosphere 2010, 79, 1033-1039. [CrossRef]

43. Kumar, B.R.; Saravanan, S. Use of higher alcohol biofuels in diesel engines: A review. Renew. Sustain. Energy Rev. 2016, 60, 84-115. [CrossRef]

44. Karabektas, M.; Hosoz, M. Performance and emission characteristics of a diesel engine using isobutanol-diesel fuel blends. Renew. Energy 2009, 34, 1554-1559. [CrossRef]

45. Jin, C.; Yao, M.F.; Liu, H.F.; Lee, C.F.F.; Ji, J. Progress in the production and application of n-butanol as a biofuel. Renew. Sustain. Energy Rev. 2011, 15, 4080-4106. [CrossRef]

46. Yao, M.F.; Wang, H.; Zheng, Z.Q.; Yue, Y. Experimental study of n-butanol additive and multi-injection on HD diesel engine performance and emissions. Fuel 2010, 89, 2191-2201. [CrossRef]

47. Armas, O.; García-Contreras, R.; Ramos, Á. Pollutant emissions from engine starting with ethanol and butanol diesel blends. Fuel Process. Technol. 2012, 100, 63-72. [CrossRef]

48. Rakopoulos, D.C.; Rakopoulos, C.D.; Giakoumis, E.G.; Dimaratos, A.M.; Kyritsis, D.C. Effects of butanol-diesel fuel blends on the performance and emissions of a high-speed DI diesel engine. Energy Convers. Manag. 2010, 51, 1989-1997. [CrossRef]

49. Valentino, G.; Corcione, F.E.; Iannuzzi, S.E.; Serra, S. Experimental study on performance and emissions of a high speed diesel engine fuelled with n-butanol diesel blends under premixed low temperature combustion. Fuel 2012, 92, 295-307. [CrossRef]

50. Rakopoulos, C.D.; Dimaratos, A.M.; Giakoumis, E.G.; Rakopoulos, D.C. Investigating the emissions during acceleration of a turbocharged diesel engine operating with bio-diesel or n-butanol diesel fuel blends. Energy 2010, 35, 5173-5184. [CrossRef]

51. Rakopoulos, D.C.; Rakopoulos, C.D.; Hountalas, D.T.; Kakaras, E.C.; Giakoumis, E.G.; Papagiannakis, R.G. Investigation of the performance and emissions of bus engine operating on butanol/diesel fuel blends. Fuel 2010, 89, 2781-2790. [CrossRef]

52. Rakopoulos, C.D.; Dimaratos, A.M.; Giakoumis, E.G.; Rakopoulos, D.C. Study of turbocharged diesel engine operation, pollutant emissions and combustion noise radiation during starting with bio-diesel or n-butanol diesel fuel blends. Appl. Energy 2011, 88, 3905-3916. [CrossRef]

53. Dogan, O. The influence of $\mathrm{n}$-butanol/diesel fuel blends utilization on a small diesel engine performance and emissions. Fuel 2011, 90, 2467-2472. [CrossRef]

54. World Health Organization (WHO). Burden of Disease from Environmental Noise. 2011. Available online: https:/ /www.who. int/quantifying_ehimpacts/publications/e94888.pdf?ua=1 (accessed on 10 March 2021).

55. Mata, C.; Gómez, A.; Armas, O. The influence of ethanol-diesel blend on pollutant emissions from different bus fleets under acceleration transitions. Fuel 2017, 209, 322-328. [CrossRef]

56. Li, W.; Ren, Y.; Wang, X.B.; Miao, H.; Jiang, D.M.; Huang, Z.H. Combustion characteristics of a compression ignition engine fuelled with diesel-ethanol blends. Proc. Inst. Mech. Eng. Part D J. Automob. Eng. 2008, 222, 265-274. [CrossRef]

57. Magand, S.; Lecointe, B.; Chaudoye, F.; Castagne, M. Optimization of a Euro 5 Vehicle powered by an ethanol based diesel fuel. SAE Int. J. Fuels Lubr. 2010, 3, 260-272. [CrossRef] 
58. Michikawauchi, R.; Tanno, S.; Ito, Y.; Kanda, M. Combustion improvement of diesel engine by alcohol addition-Investigation of port injection method and blended fuel method. SAE Int. J. Fuels Lubr. 2011, 4, 48-57. [CrossRef]

59. Magand, S.; Pidol, L.; Chaudoye, F.; Sinoquet, D.; Wahl, F.; Castagne, M.; Lecointe, B. Use of ethanol/diesel blend and advanced calibration methods to satisfy Euro 5 emission standards without DPF. Oil Gas Sci. Technol. Rev. D IFP Energ. Nouv. 2011, 66, 855-875. [CrossRef]

60. Zhang, Z.-Q.; Zhao, F.-Q.; Deng, J.; Li, L.-G. A simulated study on the performance of diesel engine with ethanol-diesel blend fuel. Therm. Sci. 2013, 17, 205-216. [CrossRef]

61. Heuser, B.; Kremer, F.; Pischinger, S.; Rohs, H.; Holderbaum, B.; Koerfer, T. An experimental investigation of dual-fuel combustion in a light duty diesel engine by in-cylinder blending of ethanol and diesel. SAE Int. J. Engines 2016, 9, 11-25. [CrossRef]

62. Taghizadeh-Alisaraei, A.; Rezaei-Asl, A. The effect of added ethanol to diesel fuel on performance, vibration, combustion and knocking of a CI engine. Fuel 2016, 185, 718-733. [CrossRef]

63. Giakoumis, E.G.; Rakopoulos, C.D.; Dimaratos, A.M.; Rakopoulos, D.C. Combustion noise radiation during the acceleration of a turbocharged diesel engine operating with biodiesel or n-butanol diesel fuel blends. Proc. Inst. Mech. Eng. Part D J. Automob. Eng. 2012, 226, 971-986. [CrossRef]

64. Satsangi, D.P.; Tiwari, N. Experimental investigation on combustion, noise, vibrations, performance and emissions characteristics of diesel/n-butanol blends driven genset engine. Fuel 2018, 221, 44-60. [CrossRef]

65. Morgul, O.K. Experimental analysis for assessing noise and vibration of the diesel engine fuelled with a butanol-diesel blend under different injection pressures and engine speeds. Int. J. Environ. Sci. Technol. 2020. [CrossRef]

66. Fastl, H.; Zwicker, E. Psycho-Acoustics: Facts and Models; Springer: New York, NY, USA, 2007.

67. Li, J.; Yu, W.; Yang, W. Evaluating performance and emissions of a CI engine fueled with n-octanol/diesel and n-butanol/diesel blends under different injection strategies. Fuel 2021, 284, 119085. [CrossRef]

68. Li, X.; Guan, C.; Yang, K.; Cheung, C.S.; Huang, Z. Impact of lower and higher alcohol additions to diesel on the combustion and emissions of a direct-injection diesel engine. Environ. Sci. Pollut. Res. 2019, 26, 21001-21012. [CrossRef] 